\title{
Domestic Violence against Women: A Case Study of District Jacobabad, Sindh Pakistan
}

\author{
Dr. Nadeem Bhatti \\ Head of Faculty, North American College \\ 730, Young Street, Suit No.207, Toronto, M4Y, 2B7, Ontario, Canada \\ E-mail:nadbhatti@yahoo.com \\ Dr. Muhammad Bachal Jamali \\ Associate Professor, Deptt:of Commerce \\ Shah Abdul Latif University Khairpur Mirs, Pakistan \\ Dr. Najma Noor Phulpoto \\ Assistant Professor, Deptt: of Sociology \\ Shah Abdul Latif University Khairpur Mirs, Pakistan \\ Dr. Tariq Mehmood \\ Assistant Professor-IER-University of the Punjab, Lahore, Pakistan
}

Faiz. M. Shaikh

Assistant Professor, SZABAC, Dokri, Pakistan

E-mail: faizshaikh@hotmail.com

Received: May 27, $2011 \quad$ Accepted: July 1, $2011 \quad$ Published: December 1, 2011

doi:10.5539/ass.v7n12p146 URL: http://dx.doi.org/10.5539/ass.v7n12p146

\begin{abstract}
The research investigates the domestic violence against women in District Jacobabad Sindh Pakistan and how women are surviving in the domestic violence in Pakistan. According to General Assembly resolution violence against women is a manifestation of historically unequal power relations between men and women, which have led to domination over and discrimination against women by men and to the prevention of the full advancement of women. Women in Pakistan encounter multiple forms of violence, most endemic form being domestic violence, which remains a pervasive phenomenon. Data were collected from both qualitative and quantitative methods were used. The qualitative methods involved initial focus group meetings that were followed by the survey questionnaire. The focus groups were felt necessary in order to make the respondents themselves identify issues that could be explored further. An open-minded approach was adopted which guided the research throughout in both qualitative and quantitative methods. The survey questionnaire was more of an in depth interview because of the sensitive nature of the issues and therefore included open ended questions with certain inferences on the types of violence recorded on a quantitative sheet. Open ended questions elicited in-depth explanations of particular issues. It was revealed that most of the surveyed women were deprived from basic rights and the biggest challenge which they ae facing like early marriages, Watta Satta marriages. It was further revealed that the rural women is less confident and their husbands were always given them hard time once they are exposing themselves to outside the boundaries of the house. The biggest challenges which they were facing they were doing all business in house, lack of marketing facilities, Karo Kari criminal activities and they were
\end{abstract}


deprived from the basic rights. The number of women who died of stove burns in the first six months of 1992 was 500 compared to 370 murders that took place at the same time. The study of women division in 1989 revealed that at least $50 \%$ of these deaths were murders linked to domestic disputes. The doctors at the Burn Unit of Mayo Hospital estimate that at least $60 \%$ of those women have been burnt by their husbands or in laws.

There are some limitations in this research because most of the survey was conducted from male and female participation due to time constraints in the sample size. A survey by a Lahore NGO Aurat Foundation attributed $50 \%$ of these deaths to accidents and $50 \%$ to murder or suicide.

Keywords: Domestic, Violence, Women, District, Jacobabad

\section{Introduction}

The United Nation Declaration on the Elimination of Violence against Women (1993) defines violence against women as "any act of gender-based violence that results in, or is likely to result in, physical, sexual or psychological harm or suffering to women, including threats of such acts, coercion or arbitrary deprivation of liberty, whether occurring in public or in private life (Note 1).

Thus the harmful customary practices which aim at preserving female subjugation, defended and sanctified as cultural traditions and given religious overtones are amongst the most pervasive forces impacting upon women dignity. As their lives are inevitably governed by the traditions of the community and tribe, women in Pakistan do not enjoy or benefit from the fundamental rights recognized in the constitution of Pakistan. "The interplay of tribal codes, Islamic Laws, Indo British judicial traditions and constancy traditions has created an atmosphere of oppression around woman (Note 2)." Keeping in view the areas identified by the secondary researches in Pakistan, the objectives identified by this primary research are to:

i) Identify the root causes of domestic violence against women

ii) Determine its state of existence and key areas of domestic violence

iii) Judge the level of awareness about the issues of domestic violence

iv) Suggest remedies to reduce the prevalence of domestic violence in women

The report begins by providing a brief background of the research and states the significance of this study. It then explains the conceptual framework which has guided the study, representing the underlying causes of domestic violence symbolically with a tree. This section is followed by the research design, which explains the methodology, and the specific methods used in conducting this research and also delineate the process of data collection. The report then presents the findings of the study that were obtained through the qualitative and quantitative methods and then uses the conceptual framework to analyse these results. The macro level issues that further perpetuate the domestic violence, which is part of the conceptual framework is also analysed in detail in the following chapter. Finally, the paper concludes with a note on the limitations and a list of policy recommendations.

\section{Stove Burning}

Over the past decades murderers attempted murder by stove burning has become more common indication of increased marital violence. Deaths by stove burning are generally attributed to be accidental bursting of stoves with onus on manufacturer or the carelessness and ignorance of women using the stove. These incidents have witnessed a phenomenal increase. An informal survey estimated that the number of deaths as a consequence of stove blast was 800 in 1989, 1100 in 1989 and 1800 in 1991 (Note 3). The number of women who died of stove burns in the first six months of 1992 was 500 compared to 370 murders that took place at the same time. The study of women division in 1989 revealed that at least $50 \%$ of these deaths were murders linked to domestic disputes. The doctors at the Burn Unit of Mayo Hospital estimate that at least $60 \%$ of those women have been burnt by their husbands or in laws. A survey by a Lahore NGO Aurat Foundation attributed $50 \%$ of these deaths to accidents and 50\% to murder or suicide. In the NWFP, the Regional Directorate of Human Rights, Ministry of Law, Justice and Human Rights reported in February that in 2000, 1000 cases of violence against women were reported. Most of these included domestic violence, including stove burning. In the Sindh, 209 cases involving burn injuries had been reported by end of December 2001 according to HRCP data. FIRs were registered in only 24 of those cases, with the injuries suffered by victims mainly attributed to accidents involving stoves, 146 of the victims of the burning died as a result of their injuries. In Karachi, according to the figures collected by HRCP 48 women had been burnt to death during the year. This is despite the fact that vast majority of cases of domestic violence are unreported. The problem intensifies when cases are not reported by hospitals police resists FIRs, no 
proper investigative techniques for circumstantial evidence is available in burn cases. It is estimated that at least 500 women in the country encountence such a miserable fate each year (Note 4).

\section{Karo-kari in Pakistan (Honour Killings)}

Over the past few years, an increased incidence of karo-kari 'blackened man, blackened woman' in Sindhi - has further blotted Pakistan's already negative women's right's record. Rooted in patriarchal and cultural perceptions of women as male property, karo-kari ostensibly takes place to avenge family 'honour' when a woman violates tribal or cultural norms (Note 5). Karo-kari is carried out when a woman and man have an illicit relationship, or are even suspected of having one, since public perception of the woman's guilt is considered sufficient to taint family 'honour'. Reports indicate that inevitably, the practice targets women, who are never given an opportunity to defend themselves against the allegations. Perceived as the embodiment of honour of their family by entering an adulterous relationship. Thus, both real and perceived the women indirectly challenge the social order as a whole. She becomes Kari (Sindhi) Siah Kari (Baluch). A large proportion of murder in the name of honour - are carried out because a couple has married or wishes to marry against the family will. Karo-kari has also taken place in situations when women seek divorce, and sometime for defiling the family or tribal 'honour' by being raped. Karis remain dishonoured even after death. Their dead bodies are thrown in rivers or buried in special hidden kari graveyards. Nobody mourns for them or honours their memory by performing the relevant rites. Karos by contrast are reportedly buried in the communal graveyard (Note 6). The distinction between a woman being guilty and a woman being alleged to be guilty of illicit sex is irrelevant. What impacts on the man's honour is the public perception, the belief of her infidelity. Rumour, belief, insinuation are enough to defile honour and demand remedial action: the killing of women.

Two main factors contribute to violence against women in the name of honour: women's commoditisation and conceptions of honour. The end result is that the right to life of women in Pakistan is conditional on their obeying social norms and traditions. The concept of women as an object or commodity, not a human being endowed with dignity and rights equal to those of men, is deeply rooted in the tribal culture. Dr Tahira Shahid Khan of Shirkatgah, a woman's resource centre, points out: "Women are considered the property of the males in their family irrespective of their class, ethnic or religious groups. The owner of the property has the right to decide its fate. The concept of ownership has turned women into a commodity which can be exchanged, bought and sold. Similarly, a close observer of women's issues in Sindh, journalist Nafisa Shah says: "In the tribal society of Sindh and Balochistan, a woman is equated with money. ... But although she has monetary value, her worth is essentially that of a commodity and this view goes far towards creating a situation when she may be butchered if she transgresses the conditions under which she is bound to a man for life. She may also be freely traded or given away as part of a karo-kari settlement." A woman raped shames the community and hence becomes the Kari. The commoditisation of women is also evident in that every marriage in tribal society involves payment of the bride price (vulver in NWFP and Baluchistan and vekro in Sindh). The girl or woman is exchanged for a price in the market. The price is paid by the groom to the father for the transfer of a commodity from the father's to the groom's/husband's possession and custody. The bride price varies according to status, health, beauty and age of the woman and, like other possessions, the bride subsequently adds to the honour of the groom. To receive a bride price in exchange for a daughter is honourable not only to the family but also to the woman concerned whose worth is thereby acknowledged.

\section{Killings under the pretext of honour}

"Honour killing was punishment for violating the honour codes but the tribes have subverted the custom of killing not for honour but to obtain the compensation that the tribal settlement awards to the aggrieved person", Nafisa Shah summarizes.38 In honour killings if both the kari and karo are killed, the matter ends; if only the kari is killed and the karo escapes -- as is often the case - he has to compensate the affected man, for the damage to honour he inflicted, for the woman's worth who was killed and to have his own life spared (Note 7). This provides easy opportunities for the unscrupulous to make money, obtain a woman in supposed compensation or to conceal other crimes. As Nafisa Shah puts it, a whole 'honour killing industry' has sprung up with a range of stakeholders including tribes people, police administration and tribal mediators. "Vested interests ... use the excuse of honour as a blanket cover for a multitude of sins." (Note 8) The desire to obtain land may also lie behind some fake honour killings. Unable to repay loans, some men are known to have killed a woman of their own family to implicate someone in the debtor's family to ensure the loan would be extinguished in compensation (Note 9). Increasingly the Karo Kari Concept is being extended to diverse situations and is used as a cover for other killings. There are several reports of men murdering an enemy and following it up by murdering a woman from their own family to give it the colour of Karo Kari. The practice has no basis in Islamic stems from tribal or feudal practice. 


\section{Watta Satta Marriages}

The Practice of Watta Satta in which a brother and sister are married to another pair of siblings continues unabated. In these barter trade marriages, if there is no exchange match available at the time, a pregnant woman in the family pledges to give her child when it is born. This custom prevails not only amongst the lower classes, in order to cut down demand of dowry but also amongst middle and upper classes. Those marriages involve abuse of two women whose marital happiness depends on actors outside their marriage. The marital or other trouble in are household would effect the relations between husband wife in the other household. S., a woman serving a life sentence for the murder of her husband in Multan jail related a story of Watta Satta marriage gone out of control. Apparently, she was given to her husband in marriage of the understanding that her husband's sister would be given to her brother as soon as she was seven year old. The husband's family refused to uphold their end of bargain and S. was taken back by her family. S. was pregnant at the time and, in order to return to her husband, she had to give her brother her new born daughter who he could then exchange for a bride for himself. This whole episode ended with a fight between her brother and her husband which led to her husband getting killed.

\section{Rape and Sexual Assault}

Rape or forcible sexual intercourse is one of the ugliest forms of violence against women and girls, as it does not end with the act itself. Rape victims often suffer a form of post-traumatic stress disorder, and other psychological problems especially those who have suffered extreme threats, terror and helplessness. Rape has also been described as the primary instrument of control in a patriarchal society and is often used as a mechanism of revenge or punishment. A very common perception about rape is that it is somehow the woman's fault, whether because of her provocative behaviour or dress or because she ventured outside the defined permissible parameters among strangers. Yet, the reality is that a number of rapes are committed in their own homes, several by people known to the women and many because she is the victim of either the man's destructive criminal lust or because of other conflicts between males. Gang-rape, which has multiplied over recent years, is used as a means of revenge not only in public places, but also in homes in front of male family members. According to press reports one woman was gang-raped every fourth day. Political, sectarian and ethnic conflicts are characterized by rape and molestation of women, including at the hands of the law-enforcing agencies. In view of the frequent occurrence and seriousness of the issue, the law in Pakistan was amended to introduce death penalty for gang-rape. Legislation however is never sufficient. It must be accompanied by behaviour change strategies as well as strong well to implement the law. Thus in Pakistan, the abuse of women in police stations is also reported to have assumed serious dimensions. A 1992 report found that 70 percent of women in police stations were subjected to sexual or physical violence, and that not a single police officer had been punished for such arcane. In the first 11 months of 1999, according to cases reported in Lahore newspapers, there were 41 victims, 6 of them minors; 21 cases were of gang-rape and 14 of torture and insult. Out of the 21 gangs of policemen alleged to have committed gang-rape only 5 individuals were held.

\section{Conceptual Framework}

Keeping in view the different pervasive forms of domestic violence prevalent in Pakistan, a conceptual framework was developed. This conceptual framework (Figure 1), symbolises a tree threatened from attacks of pesticides in the form of sexual, physical, psychological and economic forms of violence. The root cause of these forms of violence is the socio-cultural and religious factors and without addressing these remedial measures cannot be long-lasting. The tree gets oxygen from the environment and presently this environment further aggravates the situation due to lack oxygen supply in the form of poor judicial, medico legal and police system. This tree in totality represents the case of domestic violence.

\section{$<$ Insert Figure 1 Here $>$}

It was, therefore, these important areas that were formed part of the conceptual framework for doing the research. These areas as described earlier are explained as follows:

i) Physical Abuse:

Slapping, beating, kicking, strengthening stabbing, burning including stove burning disfigurement through acid throwing, ritual honour killings, Karo Kari murder, custodial abuse, torture etc

ii) Sexual Abuse:

Rape, sexual assault gang rape, coerced sex through threats, intimidation or physical force, forcing sex with others, forced marriages, child marriages, watta satta marriages, barter marriages, (giving a women in marriage as part of the settlement of a dispute), incest. 
iii) Psychological Abuse: which includes behaviour that is intended to intimidate, persecute, take away custody of children, isolation, verbal aggression, constant humiliation, seclusion (confirming women to the house).

iv) Economic Abuse: includes acts as denial of funds, denial of food and basic needs and controlling access to basic health care.

\section{Research Design}

The study anticipated that the women have an opinion about the issues of domestic violence and that violence left a negative remark in their life. A central aim of the project was to find out the specific problem areas, their underlying causes and what were the possible solutions at the macro and micro level.

\subsection{Data Collection Methodology}

Data were collected from both qualitative and quantitative methods were used. The qualitative methods involved initial focus group meetings that were followed by the survey questionnaire. The focus groups were felt necessary in order to make the respondents themselves identify issues that could be explored further. An open-minded approach was adopted which guided the research through out in both qualitative and quantitative methods. The survey questionnaire was more of an in-depth interview because of the sensitive nature of the issues and therefore included open ended questions with certain inferences on the types of violence recorded on a quantitative sheet. Open ended questions elicited in-depth explanations of particular issues. The overall emphasis of the research was on qualitative methods and data. The permission of the respondents was obtained through informal talks and visits. Focus group discussions were used build rapport with the women. Contact was also made using the team's informal networks. This rapport building was useful because respondents introduced to team as seen later, seemed to report more with detailed descriptions. In many of the cases where respondents were directly approached by the team, answers obtained seemed to be brief and to the point. The information obtained through the initial stages of contact provided the basis for planning two focus group discussions. Two focus group discussions were held which tried to further explore some of the information, elicited from the informal contacts. These focus group discussions tried to broadly was focus on questions around domestic violence. There were mixed responses from the focused group discussions with certain women sharing their experiences both positive and negative and other restraining from it because they termed it as a personal matter. Possible respondents were identified from a confidential list of families available from the Union Council office, but representing a variety of Mohall's and baradris o get a mixture of opinion across different castes and families. A total of 84 houses were selected for conducting in-depth interviews among the families, which constitute about $3 \%$ of the total number of households. Since it was qualitative research, therefore, a large number of households could not be selected. The period of administration of the survey was March, 2003. Getting information about issues on domestic violence was of a very sensitive nature; therefore, services of Lady Health Workers (LHWs) were used. These LHWs were trained as enumerators to conduct the interviews because they had direct contact with the women for more than 5 years and were considered as confidents of these women.

\section{Results and Discussions}

As highlighted in the conceptual framework there are basically 4 pervasive forms of violence and their prevalence in the target / study population is described as follows:

i) Psychological Abuse:

As part of the psychological violence teasing is a very common phenomenon and especially happens at the time of marriage when the newly wed bride is teased for brining insufficient and inadequate dowry which is not according to the demands of the in laws. Similarly not having children even after a short period of 1 year often brings about teasing remarks. On one occasion a husband asked the health professional to check his wife even after having a number of children. Also teasing takes place when a girl is born because it is considered as a bad omen and mother is blamed for the birth of girl. Birth of a second girl child results in second marriage enforced by the husband's family. There were also instances when teasing remarks were passed by mother-in-laws to the women on the occasion of buying items from male sellers. Preceding the internal conflicts / quarrels there is a forced period of isolation, which also psychologically burdens the affectees. There were two incidents where the custody of children was retained by the husband's family. On one occasion there was a quarrel and the girl was sent to her parent's home, whereas on the other occasion the husband had died and the mother-in-law sent the women to her parent's home. 
ii) Physical Abuse:

There were a large number of cases of physical violence in our sample population. Beating of the wives by the husbands was considered as a right. This beating was a common practice when there were financial constraints and problems faced by the family, the dowry brought by the girls was insufficient, birth of consecutive girls, late conception, discussing violence issues with her family etc. It was found that in 7 cases girls were forced to marry against their wishes. These girls were aware because of being educated and did not want to be a life partner with uneducated and older persons. There were three cases of WATTA SATTA.

iii) Sexual Abuse:

This was the most sensitive of the information regarding domestic violence and most difficult to get. Most of these cases go unreported. There were four instances when husband forced sex on their wives and in one instance certain inhumane methods of intercourse were used, which had negative reproductive health consequences. It was alarming to get information about an incest case, where a brother committed incest with her sister, who conceived and later administered abortion through dangerous and unsafe methods. There two cases where the father-in-law committed did the sexual abuse of his daughter-in-law. From among these two cases, when husband knew about this situation he divorced his wife and left the area, whereas in the second case father had married his teenage son with the objective of abusing his daughter-in-law. There was another instance where step son forced her step mother illicit relations.

iv) Economic Abuse:

Basic rights of having access to basic necessities of life are not provided to women in this area. Even the medicines for improving the health of women are not allowed by the husbands. It came out in the focus group discussion that husbands don't allow free medicines from the Ministry of Health thinking that these are contraceptives. Using of contraceptives if considered as a sin and against the Islamic teachings and local cultural norms. Women are not allowed to work in organisations though they do work in the fields. Women are not allowed to participate in any financial decision making.

A brief summary of the results obtained during the in-depth interviews other than the instances mentioned above are presented in tabulated form on the next page.

\section{Gender Equality and Absence of an Enabling Environment - Macro Level Conditions Perpetuating Domestic Violence}

The Constitution of Pakistan in several articles guarantees gender equality. For instance, article stipulates that: "All citizens are equal before law and are entitled to equal protection of law" and article 27 states: "There shall be no discrimination on the basis of sex alone". Of the international human rights treaties relevant to the issue of honour killings, Pakistan has ratified only the UN Convention on the Elimination of All Forms of Discrimination against Women and the UN Convention on the Rights of the Child. However, both of these conventions obligate it to act to protect the relevant rights. The objective reality is that commitments to ensure gender equality and international legal obligations to exercise due diligence in preventing, investigating and punishing violations of rights of girls and women, have not been adhered to Pakistan has failed to ensure that legal provisions, law enforcement and judicial structures ensure the full enjoyment by women of their human rights. Many of the above mentioned manifested forms of violence are ignored, condoned, or justified by invoking religion, culture or traditional beliefs. In addition, legal and judicial institutions have failed to provide adequate safeguards against women.

\section{The Hudood Ordinance}

The Hudood Ordinance promulgated in 1979 and enforced in 1980 including the offence of Zina, liable to had (Punishment), is one of the most damaging laws in the context of Pakistani women.

The Zina Ordinance includes the category "zina-bil-jabr" (zina by force) which lays out the definition and punishment for sexual intercourse against the will or without the consent of one of the parties, not validly married, in any of the following circumstances, namely:

(a) Against the will of the victim,

(b) Without the consent of the victim,

(c) With the consent of the victim, when the consent has been obtained by putting the victim in fear of death or of hurt, or 
(d) With the consent of the victim, when the offender knows that the offender is not validly married to the victim and that the consent is given because the victim believes that the offender is another person to whom the victim is or believes herself or himself to be validly married (Note 10).

The foolproof evidence required by Zina Ordinance for zina or zina-bi-jabr to hadd is if the accused confesses or there are four adult male witnesses to the act of penetration. It has been highlighted that the "Quranic Zina verse setting from the original four witnesses requirement, is not exclusive to man. "This verse refers to these four witnesses with the Arabic masculine plural "Shuhada" (witness), which grammatically include both man and woman, unless otherwise indicated. The limitation of testimony exclusively to man appears to be an incorporation into Islamic law of an antiquated custom. The exclusion of the female testimony becomes appalling when applied to Zina or Zina-bil-Jabr. "It is a clear travesty of Justice to deny a victim of rape the right to testify to this violent attach merely because she is a woman. In applying the exclusively male evidence rule to the crime of Zina-bil-Jabr, Pakistan has transformed what was merely and unfair antiquated male bias into direct violation of human rights of women (Note 11). Ironically when a zina-bil-jabr case fails for lack of four witnesses, the Pakistani legal system has more than once concluded that the intercourse was therefore consensual, and consequently has charged rape victims with zina. Thus if the evidence falls short of the stringent (and discriminatory) threshold required for imposing the draconian Hadd punishments, the accused may be sentenced to a lesser class of punishment known as Tazir, which is up to twenty-five years imprisonment and thirty lashes. At both the Hadd and Tazir levels of punishment, the burden of proof is on the prosecution to prove rape charges beyond a reasonable doubt. Short of conviction, women have been held for extended lengths of time as charges of Zina when hey allege rape. In a society where there is already extreme reluctance to report rape because of the social stigma and dishonour, women are further threatened by the law itself. The attitudes of police are heavily gender biased, with the general presumption that women who report rape are immoral or shameless. Thus, if the police is not convinced, the woman can be charged under the law as a co-accused in the crime of zina. Almost half the woman in jails today has been accused of zina, most of them awaiting trial. The vast majority are poor women. Law has been used not only to penalise rape victims, but also as a tool to enforce men's supremacy and to punish any deviation. Thus, a large number of women in jail on zina charges have been put by their own fathers, brothers and husbands. These includes girls who refuse to marry according to parental wishes, wives who wishes to separate or terminate their marriages, women who leave their homes because of abuse and women who refuse to go into prostitutions (Note 12). Ironically a girl child - who will never at any age be considered a valid witness for awarding full penalty, even if she herself is the victim of rape - is considered an adult for the purpose of fixing criminal responsibility and maximum punishment. Girls as young as 12 have received the penalty of imprisonment and lashes under the zina ordinance, and even younger ones have been charged.

The ordinance provides new weapons to man against woman by virtue of making Zina i.e. adultery and fornication crimes against the state, cognizable offences for which the police can take action (Note 13). Another deplorable result of the laws is the handle it has given to law enforcing agencies. The prisons and police lockups hold large number of under trial woman, mostly of the under privileged sections of the society, accused of Zina. Most FIRs are filed by the police themselves either on their own initiative of in collusion with women's relatives or pursuers (Note 14). The provisions of the zina ordinance are also in violation of the constitutional guarantees of equality and non-discrimination, since for the imposition of he maximum penalty the testimony of female witnesses, as well as that of Non-Muslims if the accused is a Muslim, is excluded. Even the victim's own testimony is not acceptable, because of her sex. Moreover, the law makes the Quranic requirement of four adult Muslim eyewitnesses for proof of adultery against a woman applicable to rape, and interprets the rule as requiring male witnesses. Thus, what was seen to be a protection for women under Islamic law against frivolous allegations of adultery has been used to deny them justice for rape. This essentially ensures that no rapist can ever receive the full penalty, as it is virtually impossible that a woman would get raped in front of four adult males of good character. The Qanun-e-Shahadat (Article 17) totally dismisses female witness or testimony. Thus a woman who does not have male but female witnesses, their testimony does not fulfil the evidentiary requirement and the perpetrator goes unpunished. Moreover the courts have no consistent standards for proof of rape. For example, according to Section 6(1) of the Zina Ordinance, "Penetration is sufficient to constitute the sexual intercourse necessary to the offence of zina-bil-jabr," however, the courts are divided over the extent of penetration required to constitute rape under the ordinance. Similarly, there is no clarity in the case law as to the related question of what constitutes proof of penetration.

In general, courts are reluctant to render rape convictions without supporting physical evidence and in cases where there are no "marks of violence" on the victim's body and the evidence consists solely of the victim's word against the defendant's. Thus even in case where consent has been obtained through the threat of violence, for 
example at gunpoint, limiting the possibility of struggle, judges ascribe undue significance to bodily evidence of the use of physical force and physical resistance by the woman. For example, the Federal Shariat Court overturned a lower court's conviction of rape on the grounds that medical examiners "did not observe any injury on the thighs, legs, elbows, arms, knees, face, back and buttocks of the victim," and held that "she was bound to sustain injuries ... a as she was supposed to put up resistance." (Note 15) Some of the Federal Shariat Courts rulings demonstrate that, based on prejudiced evidentiary requirements absence of bodily evidence and interpretation stemming from a disinclination to credit female testimony about rape, courts at times spontaneously and arbitrarily alter the nature of the charges leveled by the prosecution and convict the defendant of the lesser crime of illegal consensual sex instead of rape. According to Justice Javaid Iqbal "The court considers the aggrieved party or prosecutor guilty until she proves herself innocent... Thus when a woman files such a complaint of rape instead of seeing justice, she places herself at the mercy of the court (Note 16). Thus the continued enforcement of the discriminatory Zina Ordinance, inconsistent rulings by the courts, and gender bias in the criminal justice system makes it extraordinarily difficult for rape victims to get justice and continues to leave them vulnerable to wrongful prosecution for adultery or fornication.

Qisas \& Diyat Ordinance (1990) Domestic Violence in Pakistan is seldom recognized as a crime socially and officially is viewed as private, internal, family matter which cannot and should not be interfered with. It is accentuated by the fact that Pakistani law is even more inadequate in protecting women victims of domestic violence and penalizing batterers. Not explicitly prohibited by a specific, targeted, and distinct set of laws, most acts of domestic violence are encompassed by the Qisas and Diyat Ordinance of 1990, a body of Islamic criminal laws dealing with murder, attempted murder, and the crime of causing bodily "hurt" (both intentional and unintentional). In the absence of explicit criminalization of domestic violence, police and judges tends to treat it as a non-justifiable, private or family matter or, at best, an issue for civil, rather than criminal, courts. If a domestic violence is taken before a criminal court, it may be punished either by qisas (retribution) or diyat (compensation) for the benefit of the victim or his or her legal heirs. In qisas and diyat crimes, the victim or heir has the right to determine whether to exact retribution or compensation or to pardon the accused. If the victim or heir chooses to waive qisas, or qisas is judicially held to be inapplicable, an offender is subject to tazir or discretionary punishment in the form of imprisonment. In these instances, judges not only have the power to determine the extent of punishment but also to decide whether to punish the offender at all. Commentators have noted that the qisas and diyat laws have, in many respects, converted serious crimes, including murder and aggravated assault, into crimes against the individual rather than the state. One Pakistani researcher has written, "By vesting the primary right of forgiveness in the individual for such a serious crime as murder, the state has exposed the most susceptible sections of society to pressure from the powerful." The "privatization" of crimes by the qisas and diyat laws has particularly damaging consequences in cases of intra-family violence, the majority of which involve domestic abuse or spousal murder. As a result of the law, not only are women victims of domestic violence and their heirs susceptible to pressure and intimidation to waive qisas, but the concept of monetary compensation can be meaningless in a situation where payments flow from one member of the nuclear family to another (Note 17).

Furthermore, murder (Qatl-e-Amd) is not liable to qisas "when any wali [heir] of the victim is a direct descendant, how low-so-ever, of the offender (Note 18)." Thus, cases in which a woman has been murdered by her husband would be exempt from the qisas or maximum (i.e., capital) punishment for the murder if the couple in question have children, since in that case, a child or heir of the victim would also be a direct descendant of the offender. Thus if a man murders his wife from when he has a child (victims heir) and descendent of the offender, he cannot be sentenced to death. Large numbers of men murdering their wives are assured from the outset that such murder would be punished with the sentence of few years imprisonment. After the promulgation of this ordinance the number of extended family members accused of killing women has registered a phenomenal rise (Note 19). Moreover, Diyat in such cases, entailing compensation flowing from a father to his (motherless) children, would be a mockery. Although courts can impose tazir punishment in a spousal murder case of this kind, the maximum they can award is fourteen years' imprisonment. In view of the large measure of discretion given to the courts and in the light of the biased attitudes of the courts with respect to domestic violence, justice remains a far-fetched dream. The large degree of judicial discretion embodied in the qisas and diyat law has been widely criticized in light of the endemic societal and judicial discrimination against women in Pakistan. Among the dangers that arise from de-codification and an increase in judicial discretion is the opportunity for discrimination and corruption.

Honour killings are another form of intra-family violence with victims who are mostly women, who are seen as the repositories of family honour. Such killings are dealt also under the provisions of the qisas and diyat laws. 
However, courts minimize the severity of these crimes by applying to them, law principle of "grave and sudden provocation." In so doing, courts simply deem that qisas is not applicable to honour killings, and punish these crimes under Section 300(1) of the Pakistan Penal Code before its removal in 1990 when Qasas and Diyat ordinance was promulgated despite the fact that such killings are usually premeditated, not committed under sudden and severe provocation. The courts also invoke section 302 (c) of Pakistan Penal Code which allows for punishment of murder with imprisonment up to twenty five years where qisas is not applicable (Note 20). The law of Qisas \& Diyat continues implicitly to condone the customary practice to compensate murder through swara i.e. handing over women in compensation. The courts continue to accept women being handed over as part of compensation settlements. Thus the absence of equitable legal framework despite constitutional guarantees of equality, lack of will amongst enforcement agents and the judiciary obstructs the enforcement of protective and promotional laws (Note 21).

Inefficient \& Unresponsive Police System

\section{Delayed and Mishandled Processing of Complaints}

In addition to the discriminatory laws the judicial system exacerbates the problem by failing to view violence against women as a serious violation of women's human rights the judicial system is rife with serious flaws which fails to protect women as victims of violence and to prosecute perpetrators, as it is permeated with gender bias. Any venture to report rape, sexual assault, or domestic violence encounters an inefficient and abusive police system. Since police system is generally the point of first contact with the criminal justice system, women victims, in seeking justice for sexual or other assault, encounter obstacles from the very beginning of the process. Virtually all the human rights lawyers and activists interviewed by Human Rights Watch in 1999 reported that harassment, intimidation, physical abuse, and bribery of persons seeking the services of the police were common phenomenon, indicating endemic corruption and a serious lack of accountability in the police force whose psyche is infested with gender bias. Thus police officials often fail to file reports, lose reports, or even pursued women not to file a report through harassment or even abuse. In the unlikely event that a report is even filed, the police often conducts improper investigations or fail to even investigate the crime at all. Resultantly, men who have been reported to have committed these violent acts are often not arrested or even charged with crime. A prevailing view among police officials is that women who have been raped are either scorned lovers or fair family repressions, thus they fabricate within courts a story to frame the men. Police officials often view domestic violence including honour killings as a private matter to be resolved within the family or tribe not in criminal justice system (Note 22). The delay in registering FIRs has particularly detrimental consequences in cases of rape, assault, and battery because forensic evidence is critical for their successful prosecution, which in sexual assault cases, is generally extremely transient. Since the police usually do not take a woman victim for a medico legal examination to collect such evidence prior to registration of an FIR, the delay results in the loss of crucial forensic evidence and seriously undermines the prospect of securing a conviction in any subsequent criminal proceeding. In certain instances, the police overstates the complainant's evidence by arbitrarily including false incriminating details, while in others, the police is negligent in inaccurately recording the complainant's statement; and in some cases after being bribed, the police tampers with the statement after having been bribed by the accused. Though Pakistan has women's police stations that are staffed by female personnel, gender bias remains rampant within the police force because of the fact they do not receive any gender sensitization training to assist female victims of violence.

It is evident from the above that Societal misperceptions and the reluctance by law enforcement officials to investigate violence against women has created an environment in Pakistan where this violence, despite its prevalence, is rarely acknowledged and punished as a crime. In those rare instances that the cases actually make it to the court system, judges often issue gender bias decisions. Many judges render judgment in the garb of Islamic laws as interpreted by them, over the constitutions guarantee of non-discrimination and equality under the law. Gender bias and enforcement of Islamic law by the judges specifically concerning the issue of honour killings has been explained by Human Rights Watch in their report as under: "The Court explained that Quranic Verse 34 of Sura Al-Nisa establishes the men as the custodians of women", hence a man who kills another man for defiling the honour of his wife or daughter is acting in self defense (Note 23).

\section{Flawed \& Insensitive Medico legal System}

Medical evidence is central to the successful prosecution of both sexual and other bodily assault domestic violence cases. The fact that in rape cases Pakistani courts generally requires "positive proof of penetration" as well as physical evidence, such as genital injuries, to corroborate the victim's testimony to the nonconsensual nature of the intercourse renders timely and meticulous medico legal examination of victims. In many cases of 
sexual assault, medical evidence may provide the only corroboration of the complainant's case. The legal importance of a proper and thorough medico legal is underscored by the evidentiary criteria established by Pakistan Rape Laws, which require proof of penile penetration as well as corroboration of a women's allegation of rape. In light of these requirements, the inadequacy of existing examination procedures glaring. Pakistan does not have an efficient and reliable medicolegal system. In general, medicolegal examinations are performed by poorly trained doctors using inadequate facilities and equipment, which has a detrimental impact on victims of rape and sexual assault. Thus, the government's negligence towards medicolegal system is manifestation of discrimination against women who constitute the majority of rape victims. Although the medicolegal centers are theoretically operational twenty-four hours a day, women doctors are only available at specific times to perform evaluations in sexual assault cases. The medicolegal centers in the two cities viz Lahore \& Karachi are functioning with a minimum number of female doctors. Women in Pakistan's rural areas have virtually no chance of getting a timely or professional medicolegal exam. In most rural areas there are no specialized medico legal doctors, and victims of violence one supposed to obtain medico legal reports from the nearest government clinic or hospital, which often requires travelling considerable distances at substantial expense (Note 24). Medical doctors for the state who are responsible for collecting evidence of rape also tend to be biased against the victims. Similar to the police officials, many doctors believe that if a woman does not have signs of resistance such a bruises and scratches, the rape did not occur. An unmarried woman's virginity is also used to determine whether rape occur or not. If it appears that a unmarried women was not a virgin before the rape they often believe that she was not raped. In one of the interviews conducted by Human Rights Watch the head medico legal officer for Karachi while revealing a strong bias against the plight of women victims categorically denied the existence of rape, an held that "A woman who is well developed cannot be raped unless there are four or five men involved."

The doctors also lack the experience of contextualizing and interpreting detailed medical examination since a woman doctor is not available at night, and sometimes not even during the day. Victims end up making repeated trips to the center, which often requires making special transport arrangements entailing extra effort and expense. In addition each trip to the center requires the victim to coordinate with the police to secure an escort, which can be difficult. Further more, Doctors performing medico legal examinations on victims of sexual assault at the Office of Surgeon Medico legal in Lahore and the Office of the Police Surgeon in Karachi are constrained by non availability of instruments and supplies, to facilitate the identification and collection of forensic evidence. Thus, the inadequacy of examinations in Pakistan contributes to the violence against making it extremely difficult because of the factors stated above to bring successful cases against those who commit sexual assault. It also further abuses women victims by subjecting them to sometimes dangerous and often humiliating examinations as well as making them vulnerable to criminal charges of illicit sex (Note 25).

The judicial system, including to police officials, prosecutors, defense attorneys, judicial medical examiners and judges, is plagues by gender bias. This bias is reflected in the number of violent crimes against women that go unpunished, let alone investigated. it condones and exacerbates the problem by failing to view violence against women as a serious violation of women's human rights. The lack of Protection by the police and punishment by the courts exemplifies that women in Pakistan are often left to live in fear and subjugation. Women who are victims of violence often have no place to turn. They cannot turn to their families, as they fear that they will be killed for "dishonouring" their families. They cannot turn to police, as they fear being harassed or ignored. They cannot turn to court system, as they fear that the perpetrator will not be punished or, worse, that the victims themselves will be punished. The Government of Pakistan is ultimately responsible for the failure of these sectors to protect women and to guarantee women their fundamental human right to be free from violence, discrimination and inhumane treatment.

\section{State Obligations under National and International Laws}

The Constitution of Pakistan in several articles guarantees gender equality. For instance, article 25 says: "All citizens are equal before law and are entitled to equal protection of law" and article 27 states: "There shall be no discrimination on the basis of sex alone". At the global level, Pakistan has signed several International commitments to protect basic human rights and ensure gender equality. These include the United Nations Universal Declaration of Human Rights (UDHR); the Forward-Looking Strategies for the Advancement of Women (FLSAW; Nairobi, 1985); the Programme of Action agreed at the International Conference on Population and Development (ICPD; Cairo, 1994) Education for All (Jometien; 1990, and Delhi; 1993) UNCED (Rio; 1992) World Summit on Social Development (WSSD; Copenhagen, 1995) and the platform for Action signed at the Fourth World Conference on Women (FWCW; Beijing, 1995). Convention of the Right of Child 
(CRC) More importantly, Pakistan has acceded to the Convention on the Elimination of Discrimination Against Women (CEDAW 1993).

The Declaration adopted by the UN General Assembly in 1993 highlighted the commitment by the States in respect of their responsibilities, and a commitment by the international community at large to the elimination of violence against women". It also affirms that states must "exercise due diligence to prevent, investigate and, in accordance with national legislation, punish acts of violence against women, whether those acts are perpetrated by the State or by private persons". Thus article 2(e) makes it incumbent as the states to take all appropriate measures to eliminate discrimination against women by any person, organization or enterprise." The UN Convention on the Elimination of All Forms of Discrimination against Women (UN Women's Convention 1993). Moreover in Article (2) it requires state parties to end discrimination in all areas, i.e. "to take all appropriate measures, including legislation, to modify or abolish existing laws, regulations, customs and practices which constitute discrimination against women". One important issue identified in the Women's Convention is the need to eliminate cultural practices and customs that discriminate against women. Both Article 2(f) and 5(a) specifically state that State Parties agree to modify customs and practices that discriminate against women.

Pakistan is obliged "to pursue by all appropriate means and without delay a policy of eliminating discrimination against women" including "any distinction, exclusion or restriction made on the basis of sex which has the purpose of impairing or nullifying the recognition, enjoyment or exercise by women... on a basis of equality of men and women, of human rights and fundamental freedoms...". The UN Committee on the Elimination of Discrimination Against Women (CEDAW Committee), established under CEDAW, has noted that "gender-based violence is a form of discrimination which seriously inhibits women's ability to enjoy rights and freedoms on basis of equality with men. As part of its obligation to prevent violence against women as a step towards eliminating sex discrimination, the government is required to ensure that women victims of violence have access to an effective remedy for the violation of their rights. This duty to provide an effective remedy requires the government to show due diligence in investigating and prosecuting instances of violence against women.

Pakistan does not appear to have taken domestic commitments to ensure gender equality and its international legal obligations to exercise due diligence in preventing, investigating and punishing violations of rights of girls and women. It has failed to ensure that legal provisions, law enforcement and judicial structures ensure the full enjoyment by women of their human rights. Support systems for women victims of violence are woefully inadequate and no effort has been made in the field of education or the media portrayal of women to lessen and ultimately end discrimination against women. The government's inaction virtually depicts its indifference if not outright approval of the practices including the increase in honour killings.

Despite the government's control on radio and television in Pakistan, media consistently projects a stereotyped biased image of women or a romantic fiction which obscures the reality of many women's lives. These powerful media have not been utilized for human rights awareness and community education purposes which might begin to shift the entrenched culture of discrimination against women. Moreover school curriala and text books have not been reviewed in order to highlight basic gender issues as required by article 10 (c) of UN Women Convention. International commitments relating to the protection and promotion of the rights of women appear little known among members of the judiciary. The Commission of Inquiry for Women noted that "ratification [of the UN Convention on the Elimination of All Forms of Discrimination against Women] was accompanied by minimum publicity for fear of an adverse reaction from certain obscurantist elements in the country..."

It is also feared that "it would bind the government to take measures to eliminate many of the discriminatory aspects in laws which had been introduced in the garb of Islamic laws, a sensitive and controversial area that most governments are extremely reluctant to touch however much they might deplore them." Consequently most members of the government, including the judicary, are unaware of the substance of CEDAW."

\section{Limitations of the Research}

Research on domestic violence among women is hampered by the social sensitivity of the issues. Several studies around the world have collected data on family violence during the 1990's and most of them have underlined a variety of constraints leading to underestimates of this menace. There are several social constraints on collecting data on domestic violence. In Pakistan as in most other countries women are socialised to accept physical and emotional scolding as husband's matrimonial right. Such an internalised social attitude towards wife abuse is likely to make women view certain abusive conjugal behaviours as normal and limit their perceiving them as injurious or bad. AS a consequence underreporting of wife abuse is an almost inevitable outcome in data collected. Secondly women are reluctant to report wife abuse due to the social stigma associated with it. Thirdly 
women are dependent on their husband for survival and status, and as a result are likely to feel obligated not to reveal those abusive behaviours. Finally a fear of retribution for divulging information about family violence may discourage honest responses. This aspect was addressed in certain aspects by getting the data from LHWs rather than ordinary enumerators. These LHWs have over the last 5 year period developed association with the families and are considered as village doctor.

\section{Strategies and Interventions}

\section{An Integrated Approach}

Domestic violence is thus a complex problem and there is no one strategy that will work in all situations. The degree to which it is sanctioned by the society and community will naturally influence the kind of strategy needed.

Considering the interconnections between the factors responsible for domestic violence - gender discussed above - strategies and interventions should be designed within a comprehensive and integrated framework. A multi-layered strategy that addresses the structural causes of violence against women while providing immediate services to victim-survivors ensures sustainability and is the only strategy that has the potential to eliminate this scourge.

When planning strategies and interventions, there are a variety of stakeholders that should be borne in mind. Partnerships with these stakeholders can operate on several levels at once.

- At the level of the family, the stakeholders include women, men, adolescents and children.

- Within the local community, partnerships have to be developed with traditional elders, religious leaders, community-based groups, neighbourhood associations, men's groups (e.g., village farmers' associations), local councils and village level bodies. In traditional societies reliance has been on community based support mechanism to resolve issues of conflict.

- Within civil society, the range of partners include professional groups, women's and men's groups, NGOs, the private sector, the media, academia, and trade unions.

- At the state level, strategies must be designed in partnership with the criminal justice system (the police, judiciary and lawyers); the health care system; parliament and provincial legislative bodies; and the education sector.

- Key areas for intervention include:

- advocacy and awareness raising

- education for building a culture of non-violence - curricula that teaches human rights/gender issues should be included in elementary and secondary schools.

- training

- resource development

- direct service provision to victimsurvivors and perpetrators

- networking and community mobilization

- direct intervention to help victimsurvivors rebuild their lives

- legal reform

- monitoring interventions and measures

- data collection and analysis

- early identification of 'at risk' families, communities, groups, and individuals. These areas are not mutually exclusive; interventions may touch upon several areas at once.

Above all, five underlying principles should guide all strategies and interventions attempting to address domestic violence:

- prevention

- protection

- early intervention

- rebuilding the lives of victim-survivors 


\section{- $\quad$ accountability}

This section of the Digest attempts to formulate a framework for coordinated action at the policy and programme level.

\section{The family}

Women need to be empowered through education, employment opportunities, legal literacy, and right to inheritance. Human rights education and information regarding domestic violence should be provided to them because this is a matter of their absolute rights. Integrated supportive services, legal intervention and redress should be made available in situations of domestic violence.

\section{Local community}

Culture is not static, and newer forms of cultural norms need to be developed that respect women and promote their dignity and safety.

For example, religious leaders should be encouraged to re-examine doctrines and cultural practices that lead to the subordination of women and violation of their rights. Local council bodies (e.g., the 'panchayat' system in India) should play a strong role in creating a culture of non-violence, in setting up sanctions, negotiating appropriate local cultural responses to preventing violence, and monitoring respect for, and implementation of, the sanctions that are in place.

Creating awareness about the impact of domestic violence on communities conveys the importance of preventing such violence against women and children. Developing integrated responses to domestic violence through involvement of local community groups, community health workers and women serves to create sustainability and accountability, which in itself is a significant step.

PROFESSIONAL ASSOCIATIONS for doctors, lawyers, psychologists, nurses, social workers, welfare workers and other professionals are key players in opposing violence against women. Their members may come into contact with situations of domestic violence on a regular basis, but may not recognize the signs because of their own biases, background or lack of training. It is critical that such organizations build domestic violence and human rights curricula into their professional

training, and that professionals in the field receive regular training on these areas. Such associations need to develop protocols for identifying and referring cases of domestic violence to appropriate bodies, and screening measures for detection and early intervention. These protocols must be developed in collaboration with experts in the domestic violence field.

NON-GOVERNMENTAL ORGANIZATIONS (NGOs), like women's organizations, have worked in partnership with government agencies and international organizations to provide a diversity of services, and education and awareness programmes. Their capacity to continue to deliver a range of services should be strengthened, particularly in collaboration with state agencies.

NGOs have a fundamental role to play in bringing pressure on governments to ratify, or withdraw their reservations to, the international human rights instruments such as the UDHR, CEDAW and the CRC. NGOs have played a critical role in monitoring implementation of non-treaty instruments such as the UN Declaration on the Elimination of Violence against Women, the Vienna Declaration and Programme of Action, and the Beijing Declaration and Platform for Action.

THE PRIVATE SECTOR has a vested interest in addressing this problem since the costs of domestic violence to society, and industry in particular, are phenomenal in terms of low productivity, absenteeism, and staff turnover. The private sector should also be encouraged to finance preventive and support services in the local community.

THE MEDIA plays a pivotal role in both influencing and changing social norms and behaviour. Repeated exposure to violence in the media has been associated with increased incidence of aggression, especially in children. In the area of domestic violence, media campaigns can help to reverse social attitudes that tolerate violence against women by questioning patterns of violent behaviour accepted by families and societies.59 Collaboration with the media needs to focus on creating new messages and new responses to reduce domestic violence. Hence a conscious effort to make media professionals aware of the issues, can play an important role in addressing violence against women.

RELIGIOUS LEADERS AND SCHOLARS need to re-examine interpretations of religious texts and doctrines from the perspective of promoting equality and dignity for women. Many men who abuse women justify such behaviour on a religious basis, and many cultural practices that abuse and violate women are justified in the 
name of religion. Religious leaders at all levels have a responsibility to ensure that religious interpretations are not used to oppress women.

Greater collaboration is required between research and academic institutes, women's organizations, NGOs, and service providers when conducting qualitative research to deepen understanding of the causes of domestic violence, and its physical and psychological impact on women. Such research needs to be fed back to the community so that it can lead to awareness and transformation.

\section{The state machinery}

Violence against women cuts across all government sectors, with implications for all programming. It demands new levels of coordination and integration between a variety of government sectors including the criminal justice system, health, education, and employment.

\section{The criminal justice system}

LEGAL REFORM It is the responsibility of governments who have ratified international conventions and human rights instruments to harmonize their national laws in line with these instruments. One step towards upholding the right of women to equal protection under the law is to enact domestic violence legislation that specifically prohibits violence against women. Under this legislation, a woman should have protection from threats and acts of violence, safety and security for herself, her dependents and property, and assistance in continuing her life without further disruption.

THE POLICE are particularly well-positioned to provide assistance to victim-survivors, but very often their own prejudices, lack of training, and reluctance to intervene hinder them from dealing with domestic violence. Training and sensitization of police at all levels must be instituted, and guidelines must be developed to monitor police response. Police must be held accountable for their own behaviour towards victim-survivors in order to prevent secondary victimization of women at their hands.

THE JUDICIARY can strongly reinforce the message that violence is a serious criminal matter for which the abuser will be held accountable. The judge sets the tone in the courtroom and makes the most critical decisions affecting the lives of the victim, perpetrator, and children, and must therefore be sensitive to the dynamics of domestic violence in order to pass equitable verdicts. Sensitization of the judiciary to gender issues is, therefore, critical and law schools should include relevant courses in their programmes.

\section{The health care system}

The health care system is well-placed to identify women who have been abused and refer them to other services, as the vast majority of women visit a health facility at some point in their lives - during pregnancy, for example, or to get treatment for themselves or their children. The reality, however, is that far from playing a proactive role, the health care system has usually been unresponsive to women suffering from domestic abuse. Training for health care providers is necessary to guide them on the early screening and identification of women who are suffering domestic violence. Such training, as far as possible, should be integrated into existing training: Training should be supplemented with protocols to guide health care providers to implement standards. Protocols should include procedures for documentation for legal, medical and statistical purposes; legal, ethical and privacy issues; and upto- date information on local referral services. Protocols need to be culture-specific with special attention paid to respecting the rights of women.

\section{Conclusion}

The current research explores the Domestic violence against women in District Jacobabad.

Consistent support for women must be provided by all relevant sectors - the criminal justice system, health, welfare, and the private sector. Support must also be available to women via informal networks such as family, friends, neighbours, and local community groups. Men should receive one consistent message from all sectors and levels of society - that those who perpetrate violence will be held accountable. The criminal justice system must act to reinforce this message by taking action against perpetrators, as well as providing rehabilitation options for those who offend. Support services need to address associated behaviour patterns such as drug and alcohol problems or the risky sexual behaviour in which adolescent girls and boys may indulge as a result of being victimized themselves.

\section{References}

Aman. S. (1992). Kitchen Murders: why only women? The News, $20^{\text {th }}$ June. 
Hamza Alvi. (2009). Pakistani women in a changing society Human Rights Commission of Pakistan - 1999 Report. Economic Survey of Pakistan, 10.

J.A. Rehman. (1998). The legal rights of women in Pakistan: Theory \& Practice, p.9.

Nafisa Shah. (1993). Of Female Bondage. News time, January, p.44.

Nafisa Shah. (1998). A story in black: Karo Kari Killings in upper Sindh, REUTER Foundation Paper 100 ford 1998 p.5 Newsline, April, p.18.

Simi Kamal \& Asma Khan. (1997). A study of the interplay of formal and customary laws on woman, Vol. 1, p ii.

Somnath Sen. (1992). 'Military Expenditure Data for Developing Countries: Methods and Measurement', in Geoffrey Lamb and Valeriana Kallab (ed.), Military Expenditure and Economic Development: A Symposium on Research Issues, Discussion Paper no.185, The World Bank, Washington, D.C.

\section{Notes}

Note 1. The UN Declaration on the Elimination of violence against women, General Assembly Resolution, December, 1993

Note 2. Simi Kamal, Asma Khan: A study of the interplay of formal and customary laws on woman, Vvol 1, 1997, p ii

Note 3. Aman. S. Kitchen Murders: why only women? The News 20th June 1992

Note 4. Human Rights Commission of Pakistan: State of Human Rights in 2001

Note 5. Human Development in South Asia 2000: The Gender Question Mebub-ul-Haq Human Development Center p.92

Note 6. J.A. Rehman, The legal rights of women in Pakistan: Theory \& Practical, 1998, p.9

Note 7. Nafisa Shah: A story in black: Karo Kari Killings in upper Sindh, REUTER Foundation Paper 100 ford 1998 p.5

Note 8. Newsline, April 1998, p.18

Note 9. Massoudansari, "Blind Justice" in Herald, November, 1997 p.87

Note 10. Asifa Quraishi: Her Honour: An Islamic Critique of the Rape laws of Pakistan from a woman-sensitive perspective

Note 11. Asifa Quraishi: Ibid. p.9

Note 12. Asifa Quraishi: Her Honour: An Islamic Critique of the Rape Laws of Pakistan from a woman-sensitive perspective

Note 13. Hamza Alavi: Pakistani Women in a changing society

Note 14. Report of the Commission of Inquiry for Women, August 1997, p.47

Note 15. PLD 1987 FSC 11.

Note 16. Dr. Justice Javaid Iqbal, translated by Professor Nasire Iqbal "Crime against women in Pakistan" journal of South Asian and Middle Eastern Studies Vol.13, No.3, P.37-38

Note 17. Miranda Davies, ed, Women and Violence: (Atlantic Highlands N J: 2ed Books, 1994) p.217

Note 18. Pakistan Penal Code, Section 306 (C)

Note 19. Tanveer Jahan "Faces of Tyranny as mirrored in the preso" HRCP Newsletter Jan 1999 p.14

Note 20. Article 306 (c) PP Code: Also see Human Rights Watch: Crime or Custom? Violence against Women in Pakistan

Note 21. Human Rights Commission of Pakistan, State of Human Rights in 1997 p.182

Note 22. Crime of Custom? Violence Against Women in Pakistan, "Human Rights Watch, August 1999, pp 45-47

Note 23. Crime or Custom? Valence Against Women in Pakistan, "Human Rights Watch 1997"

Note 24. Human Right Watch 1999: Crime or Custom Violence against women in Pakistan

Note 25. Human Rights Watch: 1999, Ibid 
Table 1. Existence of different forms of violence among the sample households

\begin{tabular}{|c|c|c|c|c|c|c|c|c|c|c|}
\hline $\begin{array}{c}\text { Type of } \\
\text { Violence }\end{array}$ & $\begin{array}{l}\text { Kinds of } \\
\text { violence }\end{array}$ & $\begin{array}{l}\text { Parents/ } \\
\text { brothers }\end{array}$ & Husband & $\begin{array}{l}\text { Father } \\
\text {-in-law }\end{array}$ & $\begin{array}{l}\text { Mother } \\
\text {-in-law }\end{array}$ & $\begin{array}{l}\text { Brother/ } \\
\text { sister- } \\
\text { in-law }\end{array}$ & $\begin{array}{l}\text { Other } \\
\text { relatives }\end{array}$ & Both & $\begin{array}{l}\text { Brother/ } \\
\text { Sister } \\
\text {-in-law }\end{array}$ & $\begin{array}{l}\text { Other } \\
\text { relatives }\end{array}$ \\
\hline \multirow[t]{7}{*}{ Psychological } & Teasing & 2 & 15 & 1 & 12 & 10 & $\begin{array}{l}\text { Nephew, } \\
\text { step son, } \\
\text { S. } \\
\text { Father }\end{array}$ & 15 & 10 & $\begin{array}{l}\text { Nephew, } \\
\text { step son, } \\
\text { S. } \\
\text { Father }\end{array}$ \\
\hline & $\begin{array}{l}\text { Interference } \\
\text { in privacy }\end{array}$ & & 7 & & 8 & 5 & $\begin{array}{l}\text { S. Son } \\
\text { \& Father }\end{array}$ & 10 & 5 & $\begin{array}{l}\text { S. Son } \\
\text { \& Father }\end{array}$ \\
\hline & $\begin{array}{l}\text { Unwanted } \\
\text { touch }\end{array}$ & 1 & 4 & 1 & & 1 & $\begin{array}{l}\text { S. Son } \\
\text { \& Father }\end{array}$ & 1 & 1 & $\begin{array}{l}\text { S. Son } \\
\text { \& Father }\end{array}$ \\
\hline & $\begin{array}{l}\text { Teasing } \\
\text { remarks }\end{array}$ & 1 & 13 & & 17 & 6 & Nephew & 16 & 6 & Nephew \\
\hline & Isolation & & 8 & & 6 & 4 & & 7 & 4 & \\
\hline & $\begin{array}{l}\text { Custody of } \\
\text { children }\end{array}$ & & & & 2 & & & & & \\
\hline & $\begin{array}{l}\text { Participation } \\
\text { in decision } \\
\text { making }\end{array}$ & 1 & 13 & & 6 & 4 & & 8 & 4 & \\
\hline \multirow[t]{5}{*}{$\begin{array}{l}\text { Physical } \\
\text { violence }\end{array}$} & Torture & 3 & 13 & & 5 & 3 & $\begin{array}{l}\text { Nephew, } \\
\text { Step son }\end{array}$ & 7 & 3 & $\begin{array}{l}\text { Nephew, } \\
\text { Step son }\end{array}$ \\
\hline & $\begin{array}{l}\text { Honour } \\
\text { killing }\end{array}$ & & & & & & & & & \\
\hline & Burning & & & & & & & & & \\
\hline & $\begin{array}{l}\text { Forced } \\
\text { marriage }\end{array}$ & 7 & & & & & & & & \\
\hline & Inheritance & 2 & & & 1 & 1 & Nephew & 1 & 1 & Nephew \\
\hline \multirow[t]{6}{*}{$\begin{array}{l}\text { Sexual } \\
\text { violence }\end{array}$} & $\begin{array}{l}\text { By force } \\
\text { from } \\
\text { husband }\end{array}$ & 1 & 4 & 2 & & & Step son & & & Step son \\
\hline & Threat & 1 & 1 & & & & & & & \\
\hline & Unwanted & 1 & 4 & 1 & & & Step son & & & Step son \\
\hline & $\begin{array}{lr}\text { Forced } & \text { for } \\
\text { sex } & \text { with } \\
\text { others } & \\
\end{array}$ & & 1 & & & & & & & \\
\hline & Raped & & 11 & & & & Step son & & & Step son \\
\hline & Verbal sex & 1 & & & & & Step son & & & Step son \\
\hline \multirow[t]{3}{*}{$\begin{array}{l}\text { Economic } \\
\text { Violence }\end{array}$} & $\begin{array}{l}\text { Non } \\
\text { involvement } \\
\text { in financial } \\
\text { decisions }\end{array}$ & 1 & 13 & & 4 & 2 & & 13 & 2 & \\
\hline & $\begin{array}{l}\text { Job } \\
\text { permission }\end{array}$ & & 18 & & 2 & 4 & S.Father & 14 & 4 & S.Father \\
\hline & $\begin{array}{l}\text { Provision of } \\
\text { basic } \\
\text { necessities }\end{array}$ & 1 & 7 & & 2 & 1 & & 11 & 1 & \\
\hline $\begin{array}{l}\text { Social } \\
\text { Violence }\end{array}$ & $\begin{array}{l}\text { Restriction } \\
\text { on social } \\
\text { interaction }\end{array}$ & & 10 & & 8 & 2 & S.Father & 7 & 2 & S.Father \\
\hline
\end{tabular}

Sample area of population:

Sample size:

84

Mohalla Water Supply

Affectees: 64

Mohalla Shahianwala

Mohalla Shalolianwala 




Figure 1. 